\title{
Quality Assurance in Private School Reviewed From the Effectiveness of Supervision
}

\author{
Imas Eka Nurfadillah*, Nugraha Suharto \\ Educational Administration \\ Universitas Pendidikan Indonesia \\ Bandung, Indonesia \\ *ime.fadillah94@upi.edu
}

\begin{abstract}
The purpose of this research is to investigate the implementation of quality assurance in private school through supervision. Researcher study the relationship and effect of supervision toward the level of implementation in quality assurance. This research is a quantitative where A Five Likertscale questionnaire was used to analyse data using descriptive and inferential analysis. The respondent selected by simple random sampling. This research involved respondents from private school in Kota Bandung which consists of 50 teachers. This research finding the effectiveness of supervision in private school having an effect on quality assurance where encourage private school to do supervision appropriately and make innovation for capacity building.
\end{abstract}

Keywords—private school, quality assurance, supervision

\section{INTRODUCTION}

Education is the best investment for children, therefore parents send their children to the excellent education. Educational quality is one of the most important goal for educational system of the nations. People should receive the education up to standard and satisfy them. Having an educational quality is the great work. One of the system to make it happen is quality assurance. Educational quality assurance has an important role in the development of educational quality for every system [1]. Quality assurance is a proactive approach whose main task is to prevent errors. This approach aims for the quality improvement of the work with the standard and criteria from the organization [2]. One of the purpose of quality assurance is to develop a quality culture within the school to implement a strategy for the continuous improvement of quality [3]. Some researcher found that one of the factor behind the success of quality assurance in education was regular supervision [4]. Supervision is a process of reformation and development, in order to the success of education is evaluated through the effectiveness. This effectiveness is possible with an intensive supervision [5]. Supervision in school is needed to inform and discuss with teacher about method of teaching. In the supervision process, teachers are expected to improve teaching performance.
Some studies claimed that teacher preparation gain the advantage in talent training and improve teaching and classroom management [6]. Teacher have an important role to gain the quality of education, thus it depends on the way they are trained and supervised [7]. The supervisor responsible to program it. There are some role of supervisors; role are leadership, management, informative, research, investigation and counselling [5]. This research not only investigates the effectiveness of supervision which impact teacher performance, it is relating to increase the quality assurance that teachers should increase their performance to increase the quality of education. But also teacher's understanding about the concept of supervision. Teachers should know the task of the supervisor, if the supervisor did not do their duty, teacher could not develop their professional skill. The previous study found that intensive supervision is one of the successful factors to increase quality [4]. Another previous study found that the supervision include pre-supervision and post-supervision make a major contribution to the development of teacher [5]. The other study explained that supervision is a serious problem so the supervisor should do their duty regularly to increase teacher's skill [8]. Those previous studies direct that the supervisor should supervise teacher comprehensively as well as their tasks. Therefore, this research also investigates teacher's understanding the concept of supervision. Because teacher's understanding the concept of supervision include the task of supervision could contribute to achieve education's goal.

\section{METHODOLOGY}

\section{A. Study Area and Sample Selection}

This study was carried out at private school in Kota Bandung, Indonesia. The population of this research is teachers in private school. A sample size of 50 respondents as simple random method was applied by drawing the school names according to this study.

\section{B. Questionnaire Design and Data Collection}

In this research, a questionnaire method was used to collect the data, the questionnaire is adapted to Badan Standar Pendidikan Nasional (2016). The questionnaire was divided 
into section 1 and 2. Section 1 included questions regarding head teachers' supervision as one of the part of quality assurance. Section 2 was given for teacher's performance. We asked respondent to provide the information about their knowledge, their skill, their behaviour, and their preparation for teaching. A five Likert scale ranging from (1) "never", (2) "seldom", (3) "sometimes", (4) "often", and (5) "always" was used for measuring the implication of quality assurance reviewed from supervision. Before the starting the data collection, the questionnaire is research work of the effectiveness of supervision in school.

The data collection was completed during the period of 1 months from early September to last September 2020. The sample included teachers from private school, Indonesia. The questionnaires were personally distributed by the researcher and the respondents were made aware of their rights to withdraw participation at any time except while teaching.

This research also used interviews with teachers in private school to gain the understanding of the supervision. The interview with teachers were undertaken om an individual basis, with each lasting approximately 10 minutes, and were conducted by the researcher. The interviews were initially informed teacher's understanding about supervision.

\section{Data Analysis}

The collected data were inputted into the IBM Statistical Package for Social Science (SPSS) 16.0 software (Armonk, NY, USA) to conduct the required statistical analyses. The results of the study were presented using descriptive statistics. The interview with teacher transcribed in writing by researcher. The data analysed by content analyses.

\section{RESULTS AND DISCUSSION}

\section{A. Head Teacher's Supervision of the Sample}

TABLE I. HEAD'S TECHERS SUPERVISION

Descriptive Statistics

\begin{tabular}{|l|l|l|l|l|l|}
\hline & \multicolumn{1}{|c|}{ N } & \multicolumn{1}{|c|}{ Sum } & \multicolumn{2}{c|}{ Mean } & \multicolumn{1}{c|}{$\begin{array}{c}\text { Std. } \\
\text { Deviation }\end{array}$} \\
\hline & \multicolumn{1}{|c|}{ Statistic } & \multicolumn{1}{|c|}{ Statistic } & Statistic & Std. Error & \multicolumn{1}{c|}{ Statistic } \\
\hline X.1 & 50 & 208 & 4.16 & .122 & .866 \\
\hline X.2 & 50 & 201 & 4.02 & .155 & 1.097 \\
\hline X.3 & 50 & 202 & 4.04 & .148 & 1.049 \\
\hline X.4 & 50 & 193 & 3.86 & .159 & 1.125 \\
\hline X.5 & 50 & 215 & 4.30 & .141 & .995 \\
\hline X.6 & 50 & 200 & 4.00 & .151 & 1.069 \\
\hline X.7 & 50 & 166 & 3.32 & .175 & 1.236 \\
\hline X.8 & 50 & 184 & 3.68 & .165 & 1.168 \\
\hline X.9 & 50 & 182 & 3.64 & .151 & 1.064 \\
\hline X.10 & 50 & 180 & 3.60 & .162 & 1.143 \\
\hline X.11 & 50 & 211 & 4.22 & .119 & .840 \\
\hline
\end{tabular}

Table I. Cont.

\begin{tabular}{|l|l|l|l|l|l|}
\hline & \multicolumn{1}{|c|}{$\mathbf{N}$} & \multicolumn{1}{|c|}{ Sum } & \multicolumn{2}{|c|}{ Mean } & $\begin{array}{c}\text { Std. } \\
\text { Deviation }\end{array}$ \\
\hline & \multicolumn{1}{|c|}{ Statistic } & \multicolumn{1}{|c|}{ Statistic } & Statistic & Std. Error & \multicolumn{1}{|c|}{ Statistic } \\
\hline X.12 & 50 & 192 & 3.84 & .152 & 1.076 \\
\hline X.13 & 50 & 190 & 3.80 & .156 & 1.107 \\
\hline X.14 & 50 & 211 & 4.22 & .141 & .996 \\
\hline X.15 & 50 & 188 & 3.76 & .189 & 1.333 \\
\hline X.16 & 50 & 207 & 4.14 & .140 & .990 \\
\hline X.17 & 50 & 187 & 3.74 & .176 & 1.242 \\
\hline X.18 & 50 & 182 & 3.64 & .178 & 1.258 \\
\hline X.19 & 50 & 185 & 3.70 & .170 & 1.199 \\
\hline X.20 & 50 & 177 & 3.54 & .165 & 1.164 \\
\hline $\begin{array}{l}\text { Total } \\
\text { Valid } \\
\text { N (list } \\
\text { wise) }\end{array}$ & 50 & & & & \\
\hline
\end{tabular}

From data in table I above the researcher found that the data of head teacher's supervision has standard deviation near mean of the data. It means that the head teacher does the duty for supervision regularly. The researcher made the percentage for this data that head teacher's supervision has $77 \%$ value. Those results from teacher's perception toward the duty of supervisors, it means that head teachers do their roles.

\section{B. Teacher Performance of the Sample}

TABLE II. TEACHER PERFormanCE OF THE SAMPLE

\section{Descriptive Statistics}

\begin{tabular}{|l|l|l|l|l|l|}
\hline & \multicolumn{1}{|c|}{$\mathbf{N}$} & \multicolumn{1}{|c|}{ Sum } & \multicolumn{2}{|c|}{ Mean } & $\begin{array}{c}\text { Std. } \\
\text { Deviation }\end{array}$ \\
\hline & Statistic & Statistic & Statistic & Std. Error & Statistic \\
\hline Y1 & 50 & 199 & 3.98 & .109 & .769 \\
\hline Y2 & 50 & 207 & 4.14 & .103 & .729 \\
\hline Y3 & 50 & 207 & 4.14 & .103 & .729 \\
\hline Y4 & 50 & 210 & 4.20 & .118 & .833 \\
\hline Y5 & 50 & 203 & 4.06 & .112 & .793 \\
\hline Y6 & 50 & 203 & 4.06 & .112 & .793 \\
\hline Y7 & 50 & 213 & 4.26 & .121 & .853 \\
\hline Y8 & 50 & 207 & 4.14 & .090 & .639 \\
\hline Y9 & 50 & 231 & 4.62 & .085 & .602 \\
\hline Y10 & 50 & 201 & 4.02 & .097 & .685 \\
\hline Y11 & 50 & 206 & 4.12 & .117 & .824 \\
\hline Y12 & 50 & 185 & 3.70 & .125 & .886 \\
\hline Y13 & 50 & 207 & 4.14 & .099 & .700 \\
\hline Y14 & 50 & 205 & 4.10 & .125 & .886 \\
\hline Y15 & 50 & 220 & 4.40 & .103 & .728 \\
\hline Y16 & 50 & 201 & 4.02 & .129 & .915 \\
\hline Y17 & 50 & 191 & 3.82 & .127 & .896 \\
\hline Y18 & 50 & 204 & 4.08 & .102 & .724 \\
\hline & & & & & \\
\hline
\end{tabular}


Table II. Cont.

\begin{tabular}{|l|l|l|l|l|l|}
\hline & \multicolumn{1}{|c|}{$\mathbf{N}$} & \multicolumn{1}{|c|}{ Sum } & \multicolumn{2}{|c|}{ Mean } & $\begin{array}{c}\text { Std. } \\
\text { Deviation }\end{array}$ \\
\hline & Statistic & Statistic & Statistic & Std. Error & Statistic \\
\hline Y19 & 50 & 228 & 4.56 & .086 & .611 \\
\hline Y20 & 50 & 187 & 3.74 & .102 & .723 \\
\hline Y21 & 50 & 206 & 4.12 & .102 & .718 \\
\hline Y22 & 50 & 213 & 4.26 & .098 & .694 \\
\hline Y23 & 50 & 208 & 4.16 & .116 & .817 \\
\hline Y24 & 50 & 195 & 3.90 & .146 & 1.035 \\
\hline Y25 & 50 & 199 & 3.98 & .112 & .795 \\
\hline Y26 & 50 & 176 & 3.52 & .129 & .909 \\
\hline Y27 & 50 & 198 & 3.96 & .131 & .925 \\
\hline $\begin{array}{l}\text { Valid } \\
\text { N (list } \\
\text { wise) }\end{array}$ & 50 & & & & \\
\hline
\end{tabular}

From data in table II above the researcher also found that the data of teacher performance has some standard deviation near mean of the data. It means that the researcher made the percentage for this data that teacher performance has $82 \%$. It shows that this data has positive value. This data shows that teachers do their roles as well as the rules.

\section{Teacher's Understanding of Supervision}

From 50 teachers in private school there are 25 teachers considered that they understand the roles of supervisor and the concept of supervision, thus they do their job as the rules. The half teachers who understand the concept of supervision follow the instruction and are curious about their results. They always discussed about their method or student's problem to supervisor or their teachers. They also want improve their skill with join the workshop or conferences. While half teachers are enthusiastic, the other half teachers do their job because of the command of head teachers. They did not have desire to improve their skill from themselves. Supervision for them as the routine program to investigates their work.

\section{Discussion}

From the data analysis above, the researcher would like to discuss issue as follows:

- The overall head teacher's supervision was at very high level. This is possibly because head teacher as the leader. Head teacher has power to influence the followers. The teacher should follow the policy. This make the program imply easily, it depends on the head teacher want to make a good education or not.

- The overall implementation of quality assurance through supervision which shows in teacher performance at very high level too. Teacher has a good performance to preparation for a quality education.

The discussion above related to the result of interview that there are half teachers do their duty because they want to improve their skill, another half teacher do their duty because it is the command, it means that they had incorrect concept for assurance and evaluation of quality [1].

The teacher does not understand the concept of supervision and the roles of supervisor when they had the problem teacher should discuss to supervisor to increase their skill not only do the command. Because counselling with supervisor can increase their understanding [5].

\section{CONCLUSION}

From the results and discussion concluded that school should explained the concept of supervision and the essence of supervision. They also should have explained the roles of supervisor. They should have time to counselling with teacher, so we could not found the teacher who neglect their job or do their job as job not the duty. The school also should determine the schedule of supervision regularly and do the supervision regularly, it impact to teacher performance.

\section{REFERENCES}

[1] H. Ajpru, S. Wongwanich and P. Khaikleng, "Design of educational quality assurance system for driving policy of educational reform in Thailand: theory-based evaluation," Procedia-Social and Behavioral Sciences, vol. 116, pp. 1416-1422, 2014.

[2] V. Podgornik and J. Vogrinc, "The Role of Headteachers, Teachers, and School Counselors in the System of Quality Assessment and Assurance of School Work," SAGE open, vol. 7, no. 2, 2017.

[3] P. Praraksa, S. Sroinam, M. Inthusamith and M. Pawarinyanon, "A model of factors influencing internal quality assurance operational effectiveness of the small sized primary schools in northeast thailand," Procedia-Social and Behavioral Sciences, vol. 197, pp. 1586-1590, 2015.

[4] P. Thanomwan and P. Dhatthakan, "Relationship between Administrators' Competencies and Internal Quality Assurance," Procedia-Social and Behavioral Sciences, vol. 116, pp. 808-814, 2014.

[5] C. Gülșen, A. Ates and E.G. Bahadir, "The thoughts of school principals about the effects of educational supervisors on training of teachers in terms of professions," Procedia-Social and Behavioral Sciences, vol. 174, pp. 103-108, 2015.

[6] A. Veloo, M.M.A. Komuji and R. Khalid, "The effects of clinical supervision on the teaching performance of secondary school teachers," Procedia-Social and Behavioral Sciences, vol. 93, pp. 35-39, 2013.

[7] K.E. Hoque, H.B. Bt Kenayathulla, M.V. D/O Subramaniam and R. Islam, "Relationships Between Supervision and Teachers' Performance and Attitude in Secondary Schools in Malaysia," SAGE Open, vol. 10, no. 2, 2020.

[8] I.Y. Kotirde and J.B.M. Yunos, "The Processes of supervisions in secondary schools educational system in Nigeria," Procedia-Social and Behavioral Sciences, vol. 204, pp. 259-264, 2015. 